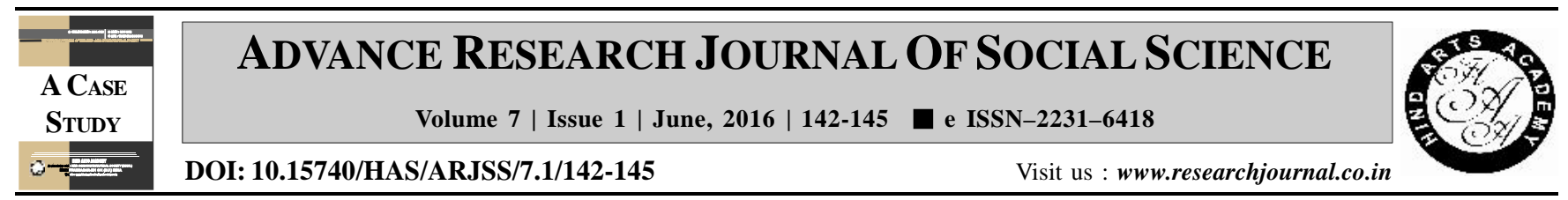

\title{
Effectiveness of modules in socio-economic upliftment of low income group rural families
}

\author{
Upasana Singh*, Sudesh Gandhi ${ }^{1}$, Pragati Singh and R.K. Dular ${ }^{2}$ \\ Krishi Vigyan Kendra, Tepla, AMBALA (HARYANA) INDIA \\ ${ }^{1}$ Department of Family Resource Management, Chaudhary Charan Singh Haryana Agricultural University, HISAR (HARYANA) \\ ${ }^{2}$ Krishi Vigyan Kendra, GURDASPUR (PUNJAB) INDIA \\ (Email: upasanarathee@ rediffmail.com,sggandhi3@gmail.com, haritaagrim@gmail.com, rkdular@gmail.com)
} INDIA

\section{ARTICLE INFO :}

$\begin{array}{lll}\text { Received } & : & 30.03 .2016 \\ \text { Accepted } & : & 25.05 .2016\end{array}$

KEY WORDS :

Upliftment, Socio-economic, Low income group, Rural families

HOW TO CITE THIS ARTICLE :

Singh, Upasana, Gandhi, Sudesh, Singh, Pragati and Dular, R.K. (2016). Effectiveness of modules in socioeconomic upliftment of low income group rural families. Adv. Res. J. Soc. Sci., 7 (1): 142-145, DOI: 10.15740/HAS/ARJSS/ 7.1/142-145.

*Author for correspondence

\section{ABSTRACT}

In rural areas, low productivity of human labor, low output efficiency is a direct result of technological deprivation and lack of awareness regarding various skill based and economically viable small enterprises especially in low income group families. In India it is the prime focus point for the central government to launch various schemes in coming years for the people having low income so that India can achieve its Vision 2020 in time. Efforts are being made to develop various modules for use, which require large-scale popularization to reach the rural families for raising their income. An attempt has been made by Krishi Vigyan Kendra, Tepla, Ambala to develop suitable module and to provide entrepreneurial skills to the rural families through module who, in turn, could use this knowledge to earn their livelihood and improve the socio-economic status of a family. The present paper attempts to study the effectiveness of modules on socio-economic upliftment of low income group rural families. Trials were conducted on a sample size of 20 LIG rural families (10 in each Module). Module-I consisted of enterprises like: Back-yard Poultry, Goatary, Kitchen Gardening with Vermi-compost and Milch animals (Buffaloes). Module-II included Back-yard Poultry, Milch animals (Buffaloes) and Stitching, Embroidery with Craft work. Small economical package was provided to selected families. Technologies selected for assessment and refinement were skill oriented trainings on Stitching and Embroidery, Kitchen Gardening, Feed for Milch Animals and Back-yard Poultry birds, Low-cost Khudda (Poultry House) and distribution of birds etc. Results revealed an active participation of farm women in the above trainings. Income generation from different enterprises was assessed as; Stitching and Embroidery (Rs. 600/-p.m.), BYP (Rs. 60-70 p.m.), Kitchen Gardens and Vermi-compost (Rs. 40/- p.m.). Conclusively, Module-II was found to be better with performance indicator for income generation of Rs. 1344/- p.m. from BYP, dairy and stitching, embroidery along with craft work and improved the socio-economic status of LIG families. Hence, there is a greater need to popularize modules and impart necessary skills so that technology adoption is favored at large-scale for uplifting the socio-economic status of low income group rural families. 